\title{
Long term growth rates and water extraction patterns of dryland chicory, lucerne and red clover
}

\author{
H.E. BROWN, D.J. MOOT and K.M. POLLOCK \\ Soil, Plant and Ecological Sciences Division, Lincoln University, P.O. Box 84, Lincoln \\ moot@lincoln.ac.nz
}

\begin{abstract}
A 5-year experiment was conducted under dryland conditions (mean annual rainfall $660 \mathrm{~mm}$ ) on a Wakanui silt loam at Lincoln University. The mean annual production of lucerne $(20 \mathrm{tDM} / \mathrm{ha})$ was greater than red clover and chicory (16 t DM/ha). The advantage of lucerne increased with time to $6 \mathrm{t} \mathrm{DM} /$ ha in the final year, when the lucerne component of the sward was $94 \%$, whereas chicory and red clover declined to 62 and $0 \%$ of their respective swards. The annual production advantage of lucerne was a result of higher growth rates in September and from December to May. The higher summer/autumn growth rates were attributed to a greater water extraction depth, giving lucerne access to more water during this time. The DM yield of all three species had a linear relationship with water use. These results are discussed in relation to the fitness of the three species for a dryland farming system, and how the performance of each would be expected to vary with differing soil type and rainfall situations.
\end{abstract}

Key words: Cichorium intybus, extraction depth, Medicago sativa, Trifolium pratense, water use, water use efficiency

\section{Introduction}

The low productivity of ryegrass/white clover pastures during periods of potential soil water deficit (Salinger 2003) is associated with their shallow root systems (Hoglund \& White 1985). The use of alternative pasture species has been suggested to improve dryland pasture production (Keoghan 1991). Chicory (Cichorium intybus ), lucerne (Medicago sativa) and red clover (Trifolium pratense) are three species that have deep tap roots that increase the amount of soil water available to the plant. These species all offer increased pasture yield in dryland conditions, but there are limitations associated with their cool season activity and persistence. However, direct comparisons to compare these attributes, and hence their suitability to dryland farming systems, are rare.
Measurement of dry matter production would provide a suitable comparison for the selection of the most productive species in the season and paddock where they are measured. However, to relate the results to other environment/soil situations, it is necessary to establish an understanding of the relationship between water use (WU) and pasture production (yield).

Yield is proportional to WU (Monteith 1988), so factors contributing to WU also effect production. Potentially, WU from evapotranspiration increases with increased temperature and solar radiation and decreases with increased humidity (Penman 1948). Water use is reduced below the crop or pastures potential when it is not fully supplied with water (Martin 1984). Water supply is derived from soil water extraction (Begg \& Turner 1976), and the extent to which water supply limits pasture growth during the season is described by the potential soil water deficit (PSWD). Salinger (2003) has suggested that PSWD in excess of $100 \mathrm{~mm}$ constitutes drought conditions that decrease pasture growth, but deeper root systems enable continued water supply and production with a higher PSWD.

We compared the seasonal growth pattern of chicory, lucerne and red clover over a 5-year period to measure their production and persistence. Water use was also measured to help explain differences and extrapolate results to other locations and environments that differ in water supply.

\section{Materials and methods}

A split-plot randomised complete block experiment was established at Lincoln University with irrigation (nil or full) as the main plots and species (chicory, lucerne and red clover) as the subplots. Main plots were $20 \times 20 \mathrm{~m}$ and separated from each other by $11 \mathrm{~m}$ of white clover guard plots. Each species was established as a monoculture to compare the potential of the three in a forage crop situation. Crops established for the remainder of the 1996/97 season, and measurements were taken from the spring of 1997 
until the end of autumn in 2002, producing data from five perennial growth seasons. This paper concentrates on results from dryland treatments, but some references are made to irrigated treatments, which are described in Brown et al. (2000).

\section{Site}

The experiment was located on flat land in Block 8 of Iversen field adjacent to the Lincoln University field service centre $\left(43^{\circ} 38^{\prime} \mathrm{S}, 172^{\circ} 28^{\prime} \mathrm{E}, 11 \mathrm{~m}\right.$ a.s.1.). The soil is classified as a Wakanui silt loam (Udic Ustochrept, USDA Soil Taxonomy) with a plant available water capacity (PAWC) of $150-200 \mathrm{~mm} / \mathrm{m}$ of depth and no physical impediments to root penetration to at least $2.3 \mathrm{~m}$ depth. This soil was selected to allow crops to fully express differences in water extraction and dryland growth patterns under conditions of high soil water extraction potential.

\section{Management}

'Grassland Puna' chicory (3.5 kg/ha), 'Grassland Kaituna' lucerne ( $7 \mathrm{~kg} / \mathrm{ha})$ and 'Grasslands Pawera' red clover $(10 \mathrm{~kg} / \mathrm{ha})$ were sown into a cultivated seed bed using an Øyjoord cone seeder on 1 November 1996. Legume sowing rates represent bare seed equivalents, but seeds were lime coated and inoculated with specific rhizobia prior to sowing.

Soil tests were conducted before establishment and during each subsequent season. Fertiliser and lime were applied to maintain fertility and $\mathrm{pH}$ at optimal levels. Herbicides were used to control weeds during the establishment phase, and herbicides were also applied during each winter to reduce weed levels (Brown et al. 2000).

All plots were grazed in common with sheep of mixed classes. The timing of each defoliation was a compromise between the ideal management for each of the three species. The first defoliation in spring aimed to minimise the risk of lodging in the lucerne, allowing the chicory and red clover to maximise their linear growth phase. The second and third defoliations were balanced between maximising linear growth rates and preventing primary flower stem formation in the chicory. Subsequent defoliations occurred when lucerne had visible flower buds, and for one regrowth period in February/March, defoliation was delayed to allow $50 \%$ of lucerne stems to develop open flowers. A final defoliation occurred after frosts stopped growth in May/June, thus six or seven defoliations occurred per season.

\section{Measurements}

Dry matter (DM) production was measured at the end of each regrowth cycle by cutting a single $0.2 \mathrm{~m}^{2}$ quadrat per plot to ground level with a set of hand shears. Subsamples were taken to determine botanical composition of crops and separated into sown and other species, with all non-sown species considered weeds. Samples were dried to constant weight in a forced air oven $\left(65-70^{\circ} \mathrm{C}\right)$.

The volumetric soil water content $\left(\theta\right.$, in $\left.\mathrm{mm}^{3} / \mathrm{mm}^{3}\right)$ was measured at 7-14 day intervals from 18 July 1997 - 25 June 2002. The $\mathrm{q}$ in the top $0.2 \mathrm{~m}$ was measured with a time domain reflectometer (Trace system, Soil Moisture Equipment, P.O. Box 30025, Santa Barbara, California, 93105, USA) and measurements from 0.2$2.3 \mathrm{~m}$ were taken at $0.1 \mathrm{~m}$ intervals with a neutron probe (Troxler Electronic Industries Inc, Research Triangle Park, North Carolina, 27709, USA). Measurements beyond $2.3 \mathrm{~m}$ depth were not possible because saturated sand collapsed the sides of auger holes, preventing aluminium access tubes being installed to a greater depth.

\section{Calculations}

Average daily growth rates were calculated from DM accumulation data. In most instances, the rate during linear growth, from the first measurement point (10$25 \%$ of maximum yield) until the time of harvest, was used. In regrowth periods where a single cut was taken prior to grazing, growth rates were calculated over the duration of the regrowth period. The seasonal pattern of growth was analysed by assigning each growth rate to the month in which the mid point of the duration occurred and displaying the monthly means from the five year duration of the experiment. Data points where sown species contributed $<75 \%$ of botanical composition were excluded.

The $\theta$ of each layer was multiplied by the layer depth $(\mathrm{mm})$ to calculate the amount of water $(\mathrm{mm})$ in each layer (Equation 1). The amounts from all soil layers were summed to obtain the total waterholding capacity of the soil to $2.3 \mathrm{~m}$ in the $2.3 \mathrm{~m}$ profile.

Equation 1 Amount per layer $(\mathrm{mm})=\theta_{\text {layer }} * \operatorname{depth}(\mathrm{mm})$

The soil water deficit (SWD) was calculated as the difference between the amount of water in the soil profile at field capacity and on measurement days (Equation 2).

Equation 2 SWD = field capacity - current profile water volume 
Water use was calculated from a water balance (Equation 3 ) using the change in SWD $(\Delta \mathrm{SWD})$ between measurement occasions and rainfall data. The $\Delta$ SWD represents soil water extraction, and daily extraction is presented as monthly means for the 1997/ 98 season.

\section{Equation $3 \quad W U=$ rainfall $-\Delta S W D$}

Equation 3 assumes no drainage occurs below $2.3 \mathrm{~m}$, and WU includes both plant transpiration and soil evaporation. Water use efficiency (WUE) was calculated from WU and DM measurements. WUE is constant in stable atmospheric conditions, but decreases as air becomes warmer or drier. The combined effect of temperature and humidity on WUE is described by the inverse proportionality of WUE to the vapour pressure deficit (VPD, represents humidity) of the atmosphere. The VPD was calculated as the difference between saturated vapour pressure and atmospheric vapour pressure from daily temperature data. The sum of VPD at daily minimum and maximum temperatures was multiplied by 0.7 to give a weighting for daylight hours (Tanner \& Sinclair 1983). WUE from each regrowth period was multiplied by the mean VPD for that period to account for the seasonal variation in VPD.

All variables were analysed using ANOVA, and means were separated using Fisher's least significant difference (LSD) test. The standard error of the mean (SEM) or LSD are displayed for each test where significant differences $(\mathrm{P}<0.05)$ occurred.

\section{Meteorological conditions}

Rainfall was recorded at the site, and all other meteorological variables were recorded at Broadfields meteorological station $2 \mathrm{~km}$ north of the site.

Long term mean daily temperature ranged from $6{ }^{\circ} \mathrm{C}$ in June/July to $18^{\circ} \mathrm{C}$ in January/February, with a mean diurnal fluctuation of $10^{\circ} \mathrm{C}$ (Figure 1a). Long-term mean rainfall was $\sim 50 \mathrm{~mm}$ per month and Penman evapotranspiration potential (EP) ranged from $40 \mathrm{~mm}$ per month in June/July to $140 \mathrm{~mm}$ per month in December/January, exceeding rainfall from September-April (Figure 1b). Rainfall was the most variable of the weather characteristics, and the resultant calculation of PSWD (Equation 4) demonstrates the accumulated difference between rainfall and EP throughout each season (Figure 1c).

Equation $4 \mathrm{PSWD}=\mathrm{PSWD}_{\mathrm{i}-1}+$ rainfall $-\mathrm{EP}$

Where PSWD ${ }_{\mathrm{i}-1}$ is the PSWD of the previous day.
The driest season was 1997/98, where an annual rainfall of $466 \mathrm{~mm}$ led to maximum PSWD $689 \mathrm{~mm}$. The maximum PSWD in 1998/99 (596 mm) and 2000/01 (461 $\mathrm{mm}$ ) were also larger than the long-term average (390 $\mathrm{mm})$. Irrigation $(150 \mathrm{~mm}$ ) was applied to dryland crops in September 1998 to reduce the SWD from the previous season, and this reduced the PSWD of these plots to $396 \mathrm{~mm}$ in $1998 / 99$. The wettest season was 1999/00, when rainfall was $844 \mathrm{~mm}$ and PSWD was $105 \mathrm{~mm}$.
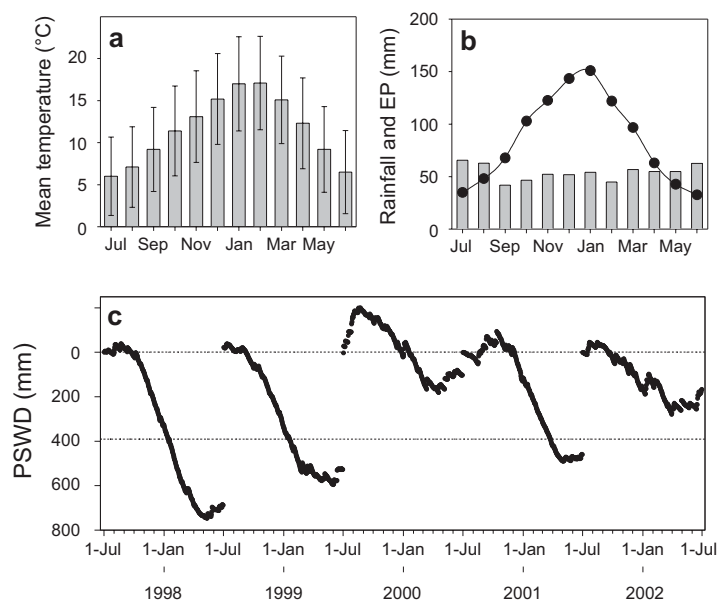

Figure 1 Meteorological data from Broadfields station. a) Long-term monthly mean of daily temperature; lines represent mean diurnal range. b) Long-term mean of monthly rainfall ( $\square$ ) and Penman evapotranspiration (EP, •) sums. c) Daily potential soil water deficit (PSWD) from 1 July 1997 to 30 June 2002, values were reset to zero on the first of July each season.

\section{Results}

\section{Annual yield and botanical composition}

Lucerne had a greater $(\mathrm{P}<0.01)$ total annual yield than red clover and chicory in all five seasons (Table 1). Specifically, lucerne produced $21 \mathrm{tDM} / \mathrm{ha}$ in 1997/98, which was $4 \mathrm{t} \mathrm{DM} /$ ha greater $(\mathrm{P}<0.001)$ than chicory and red clover. Lucerne production remained $>20 \mathrm{t}$ $\mathrm{DM} / \mathrm{ha}$ in 1998/99 and 1999/00, and was at least $4 \mathrm{t}$ $\mathrm{DM} /$ ha greater $(\mathrm{P}<0.01)$ than chicory or red clover during these seasons. Annual yields of all species were lower in 2000/01 and 2001/02, but the yield of lucerne $(\sim 18 \mathrm{t} \mathrm{DM} / \mathrm{ha})$ was still greater $(\mathrm{P}<0.001)$ than chicory and red clover ( $\sim 11 \mathrm{t} \mathrm{DM/ha)}$.

All plots maintained 100\% sown species during 1997/ 
Table 1 Total annual dry matter production (t DM/ha) and botanical composition (\%) of three herbage species grown in dryland conditions over five seasons at Lincoln University, Canterbury, New Zealand.

\begin{tabular}{|c|c|c|c|c|c|}
\hline & $1997 / 98$ & $1998 / 99$ & $1999 / 00$ & $2000 / 01$ & $2001 / 02$ \\
\hline \multicolumn{6}{|l|}{ Annual yield } \\
\hline Chicory & $15.7_{B}$ & $13.4_{B}$ & $16.4_{\mathrm{B}}$ & $12.8_{B}$ & $10.9_{B}$ \\
\hline Lucerne & $21.3_{\mathrm{A}}$ & $21.3_{A}$ & $20.3_{A}$ & $19.3_{\mathrm{A}}$ & $17.5_{\mathrm{A}}$ \\
\hline Red clover & $16.9_{B}$ & $15.1_{B}$ & $11.7_{\mathrm{c}}$ & $11.0_{C}$ & $11.5_{B}$ \\
\hline SEM & 0.51 & 0.85 & 0.66 & 0.55 & 0.54 \\
\hline Probability & $P<0.001$ & $P<0.01$ & $P<0.001$ & $P<0.001$ & $P<0.001$ \\
\hline \multicolumn{6}{|c|}{ Botanical composition } \\
\hline Chicory & 100 & 100 & $88_{B}$ & $83_{B}$ & $61_{\mathrm{B}}$ \\
\hline Lucerne & 100 & 100 & $99_{\mathrm{A}}$ & $97_{\mathrm{A}}$ & $94_{\mathrm{A}}$ \\
\hline Red clover & 100 & 100 & $54_{C}$ & $17_{\mathrm{C}}$ & $0_{c}$ \\
\hline SEM & & & 1.45 & 3.29 & 2.36 \\
\hline Probability & & & $P<0.001$ & $P<0.001$ & $P<0.001$ \\
\hline
\end{tabular}

Note: Total annual production includes sown crops and weeds. SEM is the standard error of the mean for each season. Values with different subscripts are different $(\alpha=0.05)$ according to Fisher's LSD test.

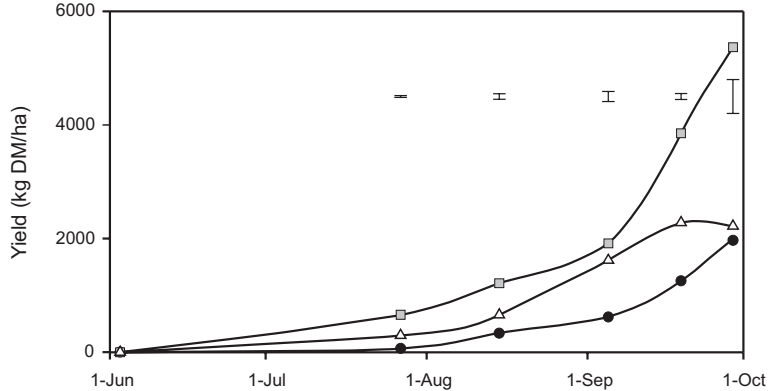

Figure 2 Dry matter accumulation from 4 June -27 September 1997 for chicory $(\bullet)$, lucerne $(\square)$ and red clover $(\Delta)$ crops grown at Lincoln University, Canterbury, New Zealand. Bars represents LSD for each measurement.

98 and 1998/99, but this started to decline in the 1999/ 2000 season (Table 1). Lucerne crops were still 94\% pure in $2001 / 02$, but chicory composition decreased to $83 \%$ by $2000 / 01$ and was only $61 \%$ in $2001 / 02$, while red clover declined $(\mathrm{P}<0.001)$ to 17 and $0 \%$ in those seasons, respectively.

\section{Seasonal production patterns}

Lucerne consistently produced the greatest $(\mathrm{P}<0.01)$ yield in the first spring regrowth period of each season. Figure 2 shows an example for the 1998/ 99 season, where the accumulation of final yield on 27 September was measured from the previous measurement on 6 June in 1998. Production was low during the winter, but by 5 September, lucerne had produced $2000 \mathrm{~kg} \mathrm{DM} / \mathrm{ha}$, which was greater $(\mathrm{P}<0.05)$ than red clover (1 $800 \mathrm{~kg} \mathrm{DM} / \mathrm{ha})$ and chicory (800 kg DM/ha). After this time, DM accumulation was linear, and by 27 September lucerne had produced $5500 \mathrm{~kg}$ $\mathrm{DM} /$ ha compared $(\mathrm{P}<0.01)$ to $\sim 2000 \mathrm{~kg} \mathrm{DM} / \mathrm{ha}$ for chicory and red clover.

The superior spring production of lucerne was also shown by a 5 -year mean growth rate of 34 $\mathrm{kg} \mathrm{DM} / \mathrm{ha} /$ day in September compared with $18 \mathrm{~kg} \mathrm{DM} / \mathrm{ha} /$ day for chicory and red clover (Figure 3). There was no difference in DM production during the later part of spring, and all species had a growth rate around $70 \mathrm{~kg} \mathrm{DM} / \mathrm{ha} /$ day in November. Lucerne growth rates in December and January $(90 \mathrm{~kg} \mathrm{DM} / \mathrm{ha})$ were $20-30 \mathrm{~kg} \mathrm{DM} /$ ha/day greater $(\mathrm{P}<0.01)$ than chicory and red clover respectively, and this advantage $(\mathrm{P}<0.01)$ remained in February despite all growth rates declining by $40 \mathrm{~kg} \mathrm{DM} /$ ha/day. Lucerne growth rates declined further from 40 to $20 \mathrm{~kg} \mathrm{DM} /$ ha/day from March to May, but were at least $10 \mathrm{~kg} \mathrm{DM} /$ ha/day greater $(\mathrm{P}<0.01)$ than chicory and red clover during these months.

\section{Water use efficiency}

The high $\mathrm{R}^{2}$ values of $0.83-0.96$ indicate DM yield was strongly correlated to WU corrected for VPD effects in the 1997/98 season (Figure 4). All three species had the same slope ( $46 \mathrm{~kg} \mathrm{DM} / \mathrm{mm} / \mathrm{kpa})$, indicating that they have the same WUE. The first regrowth period was omitted from Figure 4 because soil water measurements only started part way through the first regrowth period. Higher rainfall in following seasons (1998/99-2001/02) increased evaporation losses and caused deviation from the 


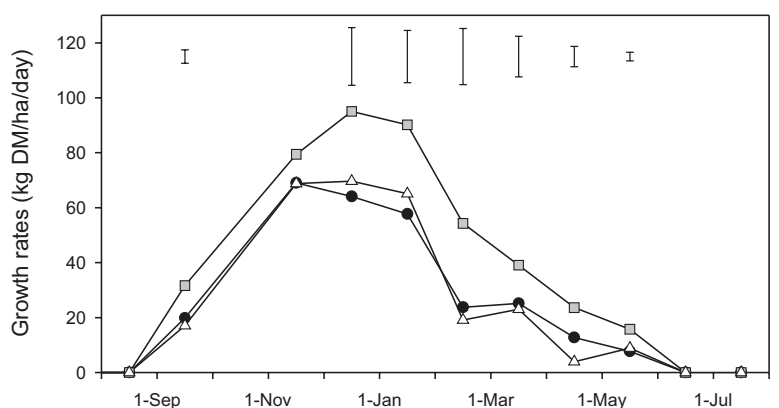

Figure 3 Five year mean growth rates of dryland chicory $(\bullet)$, lucerne $(\square)$ and red clover $(\Delta)$ crops grown at Lincoln University, Canterbury, New Zealand from 1 July 1997 to 24 June 2002. Bars represent LSD in months that species were different.

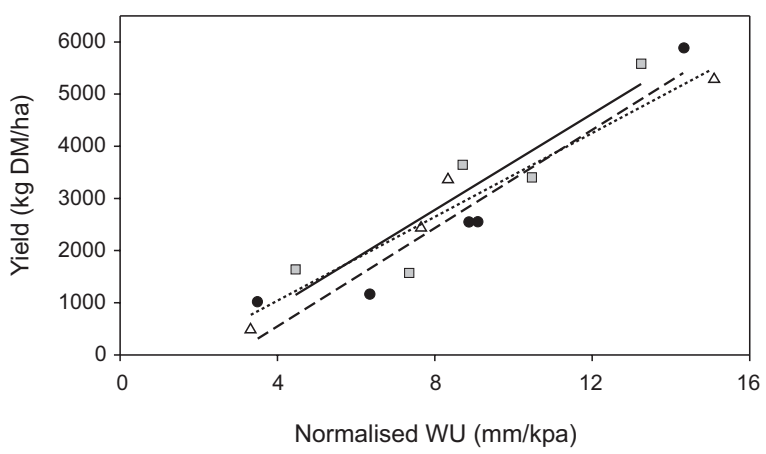

Figure 4 Yield in relation to water use (WU) normalised for vapour pressure deficit for chicory $(\bullet,---)$, lucerne $(\square,-)$ and red clover $(\Delta, \cdots)$ grown from 13 October 1997 - 29 May 1998 at Lincoln University, Canterbury, New Zealand. Note: Chicory $=-1328(724)+46.9(7.9) * \mathrm{WU} /$ kpa $\left(R^{2}=0.92\right)$, lucerne $=-908(1084)+$ $46.1(11.6){ }^{*} \mathrm{WU} / \mathrm{kpa}\left(\mathrm{R}^{2}=0.83\right)$ and red clover $=-563(632)+42.1(12.5)^{*} \mathrm{WU} / \mathrm{kpa}\left(R^{2}=0.96\right)$. Bracketed values represent SE for coefficients.

strong relationship between WU and DM during these seasons (data not shown).

\section{Water extraction pattern}

The 1997/98 season was the driest (\% less than average) and hence created greatest demand for water extraction. The patterns of extraction are displayed for this season (Figure 5), when crops still consisted of $100 \%$ sown species and water extraction potential was most likely to be expressed fully. Figure 5 displays the upper and lower limits of extraction, and the difference between the two is the actual water extracted, this is summed over the depth of the profile to give the total water extraction. Lucerne extracted $358 \mathrm{~mm}$ during this season, which was greater $(\mathrm{P}<0.01)$ than chicory or red clover $(330$ $\mathrm{mm})$. This difference came from greater $(\mathrm{P}<0.01)$ extraction below $1.5 \mathrm{~m}$. Lucerne extracted $20 \mathrm{~mm}$ from $2.0-2.3 \mathrm{~m}$, whereas chicory and red clover had maximum extraction depths of 2.0 and $1.9 \mathrm{~m}$, respectively.

The seasonal distribution of water extraction in 1997/98 is displayed in Figure 6, where all three species started extracting water in September, and extraction was the same as PSWD during September and October. Water extraction was less than potential during November and December, but there were no differences among species during this time. The deeper extraction by lucerne gave greater $(\mathrm{P}<0.05)$ water extraction from January-March (Figure 5). An additional calculation was made that assumed lucerne extracted the same amount of water per layer from the 2.3-2.7 $\mathrm{m}$ depth, which is below the measurement depth. This is also displayed in Figure 6 to show the theoretical advantage of lucerne if roots are indeed extracting water to this depth.

\section{Soil water deficit}

The high variability in PSWD also occurred for measured SWD. The greatest $(\mathrm{P}<0.05)$ SWD occurred in 1997/98 (Figure 7). During that season, lucerne had a maximum deficit of $407 \mathrm{~mm}$, which was $65 \mathrm{~mm}$ greater $(\mathrm{P}<0.05)$ than chicory and red clover. Lucerne had a maximum SWD $>350 \mathrm{~mm}$, which was $80-100 \mathrm{~mm}$ higher $(\mathrm{P}<0.05)$ than chicory and red clover in 1998/99, 2000/01 and 2001/02. The smallest SWD recorded was in 1999/00, season when all species had a maximum deficit of $250 \mathrm{~mm}$. Rainfall returned the SWD close to zero (field capacity) in spring for red clover and chicory in four of the five seasons, but lucerne only reached zero in the spring of 2000/01. In 2001/02, the minimum SWD of chicory and red clover was $150 \mathrm{~mm}$ compared with $200 \mathrm{~mm}$ for lucerne.

\section{Discussion}

\section{Annual production}

Annual lucerne yields were 4-6 t DM/ha higher than from chicory and red clover under dryland conditions in 1997/98 and 1998/99 when all three stands were pure (Table 1). Combined with greater persistence 


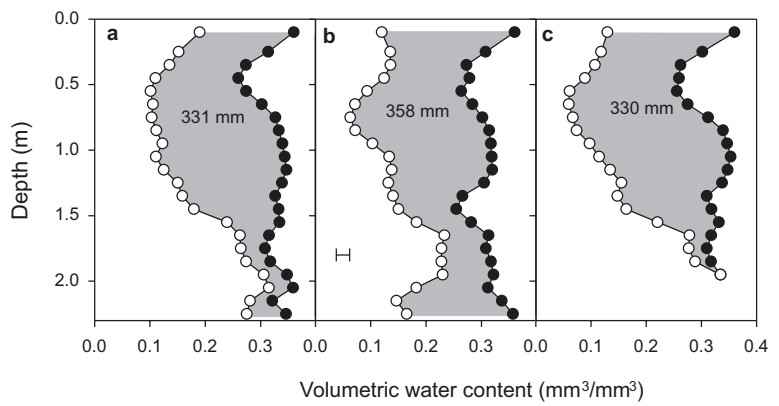

Figure 5 Volumetric water content of soil at upper $(\bullet)$ and lower $(O)$ limits of a) chicory, b) lucerne and $c$ ) red clover water extraction measured to 2.3 m depth from 18 August 1997 - 29 May 1998 at Lincoln University, Canterbury.

Note: Shaded area and numbers represent the total water extraction.

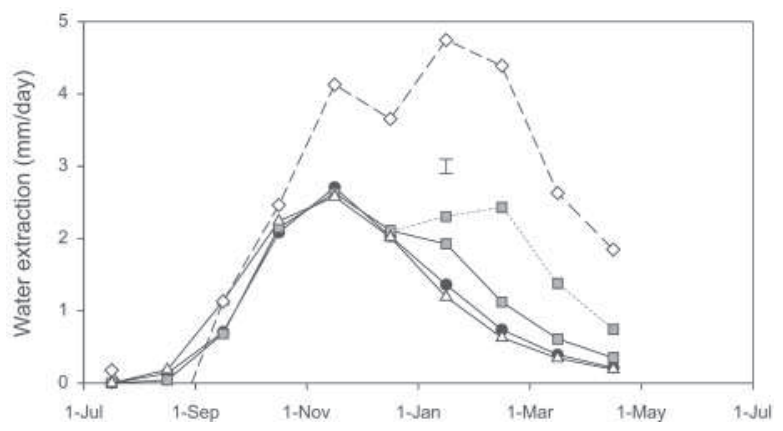

Figure 6 Monthly mean of daily soil water extraction in the $1997 / 98$ season for chicory $(-\bullet)$ lucerne $(--)$ and red clover $(-\triangle)$ ) to $2.3 \mathrm{~m}$ depth, and lucerne to $2.7 \mathrm{~m}$ depth $(\cdots \cdot \cdot \cdot)$. Monthly mean of daily potential soil water deficit (-- $\checkmark-)$ was calculated from Broadfields Meteorological station. Bars represent LSD for species comparison in all months.

and higher yields from 1999/00-2001/02, these data highlight lucerne as the most productive of these forages. The annual lucerne yield of $20 \mathrm{t} \mathrm{DM} /$ ha was consistent with previous reports of lucerne production on soils with high PAWC (Douglas 1986). However, chicory and red clover yields were higher than previous reports in dryland conditions on shallow soils (Hunter et al. 1994; Allen et al. 1976).

Dry matter production in relation to water use The higher yields reported in this study compared with those on lighter soil are explained by the constant relationship between WU and DM yield (Figure 4). A higher PAWC allows greater water extraction and increased WU, producing increased yield. This relationship can also be used to extrapolate results

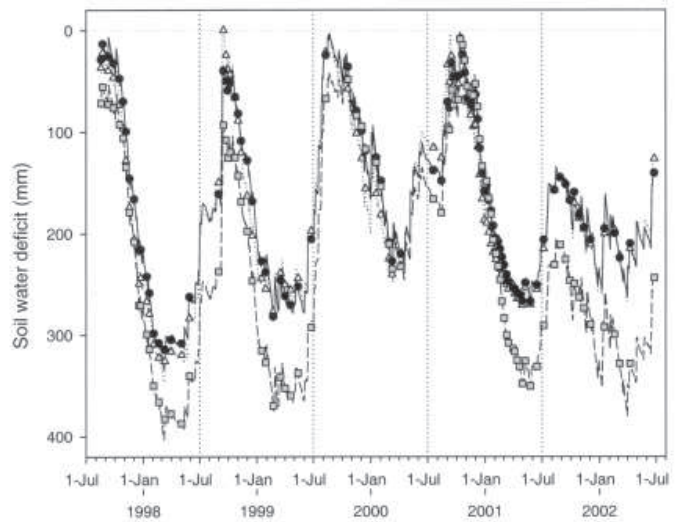

Figure 7 Measured soil water deficit to $2.3 \mathrm{~m}$ of dryland chicory (-๑), lucerne (-$--)$, and red clover $\left(\cdots \triangle \triangle^{*} \cdot\right)$ from 18 August 1997 - 24 June 2002 at Lincoln University, Canterbury, New Zealand.

from this experiment to soils of lower PAWC and different rainfall scenarios that would change crop WU.

\section{Early spring production}

Lucerne had the highest growth rates during September (Figure 3), and as a result used water more efficiently overall. This is because early in the season, air temperatures and VPD are both low (Figure 1), which causes a higher WUE (Monteith 1993). This means less soil water reserves are used to produce a higher yield than the same amount of WU during a hot period. The low temperatures also depress growth rates (Radcliffe \& Baars 1987), but the higher yield of lucerne indicates it has greater cool season activity than chicory and red clover. The advantage of lucerne during this time is reliable because water demand is low and winter rainfall has recharged the soil water (Figure 7).

Dryland farming systems have been developed with the highest feed demand in spring when lambs are being weaned and potentially finished for slaughter (Hoglund \& White 1985). During this period, feed conservation from forage crops is also common, and current results show lucerne can provide greater yields of hay or silage than chicory or red clover. This results in increased feed reserves for winter or extended dry spells.

A limitation of all three species is the need for rotational grazing and this restricts the versatility of their use for lambing. In this experiment, $3 \mathrm{t} \mathrm{DM} / \mathrm{ha}$ 
was available from lucerne for ewes and lambs (Moot et al. 2003) by mid September compared with about half this amount for chicory and red clover (Figure 2).

\section{Late spring production}

By October/November, all three species had the same growth rate (Figure 3), indicating similar production potential when mean daily temperatures exceed $10^{\circ} \mathrm{C}$ (Figure 1). All three species extracted water from the soil at the same rate as PSWD (Figure 6), indicating that water supply was non-limiting (i.e. $\mathrm{WU}=\mathrm{EP}$ ). This was consistent with irrigated treatments that had the similar yields when temperature exceeded 10 ${ }^{\circ} \mathrm{C}$ and water was non-limiting (Brown et al. 2000).

The average growth rates of $70-80 \mathrm{~kg} \mathrm{DM} / \mathrm{ha} /$ day in November, compared with 40-50 kg DM/ha/day for ryegrass/white clover pastures (Hayman \& McBride 1984), show the potential of all three species to increase production during this time. A similar advantage of lucerne over pasture (ryegrass/white clover) was displayed near Taupo, where spring lucerne production was twice as high as pasture (Baars et al. 1975). The yield advantages of these three crops during this time contribute to feed requirements for finishing lambs and any surplus is useful for making hay/silage.

Late spring production is less reliable than early spring because WUE is lower (temperature and VPD are higher) and water demand is higher, making it more likely WU will limit growth. The most reliable feed supply during this time is produced on deep soils, such as those used in this experiment. However, on lighter soils, with lower PAWC, water reserves may be depleted by this time, and growth depends on rainfall. The advantage of deep soils may be reduced in situations where the soil profile is not recharged completely during the winter. A demonstration of this scenario occurred in 2001/02, when the SWD of chicory and red clover only recovered to $150 \mathrm{~mm}$ during the winter (Figure 7). However, high rainfall (844 mm) during the 2001/02 summer/autumn meant reductions in WU, and yields were minimal. The SWD of lucerne only reached $200 \mathrm{~mm}$ at the start of 2001/ 02 , and DM production would have been reduced had the summer been dry.

A recommendation to compensate for the low cool season activity of chicory and red clover is to sow them in mixtures with ryegrass. However, the cool season activity of ryegrass would also deplete soil water reserves early in the season and consequently reduce the potential growth of companion red clover or chicory later in the season.

\section{Summer/autumn production}

Lucerne had greater summer/autumn production than chicory and red clover because it had a greater extraction depth (Figure 5) and subsequently, a greater summer water supply than chicory and red clover (Figure 6). Water supply is made up of soil water extraction and in-season rainfall. Therefore, reduced rainfall has less effect on the annual water use and subsequent production of a deep-rooted species because a greater proportion of its water use is derived from water extraction. This was demonstrated by Douglas (1986), where the relative yield advantage of lucerne over pasture increased as annual rainfall decreased.

The advantage of deep roots is greatest on soils with deep layers of fine material and consequently high PAWC. A demonstration of this was given by Hayman \& McBride (1984), who showed annual lucerne yield on a deep silt loam soil was $6 \mathrm{tDM}$ /ha greater than on a stony soil, whereas pasture yield was only $4 \mathrm{t} \mathrm{DM/}$ ha greater on the deep soil. Thus, to realise the potential yield advantage of deep-rooted species they should be planted on the deepest free draining soils rather than shallow soils. This also enables the best soils to realise their potential as shallow rooted pastures may leave water in the subsoil that lucerne could have utilised for DM production.

Lucerne roots often reach in excess of $3 \mathrm{~m}$ depth (Sheaffer et al. 1988) and even on soils of low PAWC the great depth of root penetration may provide water for one or two weeks more growth than ryegrass/ white clover pastures (Douglas, 1986). Any additional water extraction beyond this averts dormancy, may allow faster recovery and utilization of summer rainfall almost immediately. Dormant plants take longer to reestablish a leaf area and will lose a large proportion of summer/autumn rainfall from soil evaporation.

The summer growth rate of all three crops was 50-80 $\mathrm{kg} \mathrm{DM} /$ ha/day. This was substantially higher than the $15-30 \mathrm{~kg} \mathrm{DM} / \mathrm{ha} /$ day expected from dryland ryegrass/white clover pastures during summer in Canterbury on the same soil type (Hayman \& McBride 1984). Summer production is useful for finishing lambs or providing some green forage for ewes when ryegrass/white clover are typically dry or dormant due to drought. This is also the time of greatest drought risk because water demand is highest (Figure 
1b) and WUE is lowest (Monteith 1993). The risk of drought increases as PAWC of the soil decreases, and no species can be expected to provide substantial yields during severe summer dry periods, especially on light soils. The greater spring production from lucerne can provide hay or silage to carry more stock through a dry summer/autumn.

\section{Conclusions}

- Lucerne had a mean annual yield of $20 \mathrm{t} \mathrm{DM/ha}$ compared to $14 \mathrm{tDM} /$ ha for chicory and red clover.

- Lucerne also had greater persistence, contributing $94 \%$ of the crop DM in the fifth season compared with $62 \%$ for chicory and $0 \%$ for red clover.

- The yields of chicory, lucerne and red clover were all related linearly to water use and their water use efficiencies were similar. Therefore, all will produce lower yields on shallow soils or in lower rainfall situations where less water is available.

- The September growth rate of lucerne was $34 \mathrm{~kg}$ $\mathrm{DM} / \mathrm{ha} /$ day, compared with $18 \mathrm{~kg} \mathrm{DM} / \mathrm{ha} /$ day for chicory and red clover, showing greater cool season activity of lucerne.

- Lucerne growth rates declined from $90 \mathrm{~kg} \mathrm{DM} /$ ha/day in December to $20 \mathrm{~kg} \mathrm{DM} / \mathrm{ha}$ in May and were $20-50 \%$ higher than chicory and red clover during this time.

- The greater summer/autumn growth of lucerne is due to the greater extraction depth, providing a greater water supply.

\section{ACKNOWLEDGEMENTS}

Hamish Brown wishes to acknowledge the Foundation for Research, Science and Technology for stipend support and the Sinclair Cummings Trust for research funding.

\section{REFERENCES}

Allen, R.B.; McDonald, I.R.; Cullen, N.A. 1976. Herbage production of pasture legumes at three sites in Otago. Proceedings of the New Zealand Grassland Association 37: 182-195.

Baars, J.A.; Radcliffe, J.E.; Brunswick, L. 1975. Seasonal distribution of pasture production in New Zealand. 6. Wairakei, pasture and lucerne production. New Zealand Journal of Experimental Agriculture 3: 253-258.

Begg, J.E.; Turner, N.C.; 1976. Crop water deficits. Advances in Agronomy 28: 161-217.
Brown, H.E.; Moot, D.J.; Pollock, K.M.; Inch, C. 2000. Dry matter production of irrigated chicory, lucerne and red clover in Canterbury. Proceedings of the New Zealand Agronomy Society 30: 129-137.

Douglas, J.A. 1986. The production and utilization of lucerne in New Zealand. Grass and Forage Science 41: 81-128.

Hayman, J.M.; McBride, S.D. 1984. The Response of Pasture and Lucerne to Irrigation. Winchmore Irrigation Research Station, Ministry of Agriculture and Fisheries Technical Report. 17.

Hoglund, J.H.; White, J.G.H. 1985. Environmental and agronomic constraints in dryland pasture and choice of species. pp. 39-44. In: Using herbage cultivars. Eds. Burgess, R.; Brock, H. New Zealand Grasslands Association, Palmerston North, New Zealand.

Hunter, R.M.; Knight, T.L.; Hayes, G.; Allan, B.E. 1994. Evaluation of dryland forage species for lowland Marlborough and mid Canterbury. Proceedings of the New Zealand Grassland Association 56: 149-153.

Keoghan, J. 1991. Future options for dryland pastures. Supporting papers for the NZ meat research and development council - sponsored field day held at Belfield, Hakataramea, 17 December 1991. MAF Technology, Invermay Agricultural Centre, Mosgiel, New Zealand

Martin, R.J. 1984. Potential evapotranspiration and pasture growth in Canterbury. Proceedings of the Agronomy society of New Zealand 14:117-124.

Monteith, J.L. 1988. Does transpiration limit the growth of vegetation or vice versa? Journal of Hydrology, Netherlands 100: 57-68.

Monteith, J.L. 1993. The exchange of water and carbon by crops in a Mediterranean climate. Irrigation Science 14: 85-91.

Moot, D.J.; Brown, H.E.; Pollock, K.M.; Teixeira, E.I. 2003. Crop growth and development affect seasonal priorities for lucerne management. In: Moot, D.J. (ed.) Legumes for dryland pastures. Proceedings of a New Zealand Grassland Association symposium, Lincoln University, 1819 November 2003. Grassland Research and Practice Series. Grassland Research and Practice Series. no. 11: 201-208.

Penman, H.L. 1948. Natural evaporation from open water, bare soil and grass. Proceedings of the Royal Society of London. A 194: 120-145.

Radcliffe, J.E.; Baars, J.A. 1987. The productivity of temperate grasslands. pp. 7-17. In: Ecosystems of the world. Ed. Snaydon, R.W. Elsevier Science Publishers, Amsterdam, Netherlands. 
Salinger, J. 2003. Climate reality-actual and expected. In: Moot, D.J. (ed.) Legumes for dryland pastures. Proceedings of a New Zealand Grassland Association symposium, Lincoln University, 1819 November 2003. Grassland Research and Practice Series. no. 11: 13-19.

Sheaffer, C.C.; Tanner, C.B.; Kirkham, M.B. 1988. Alfalfa water relations and irrigation. pp. 373-409.
In: Alfalfa and alfalfa improvement. Eds. Hanson, A.A; Barnes, D.K.; Hill, R.R. Jr. Madison, Wisconsin, USA

Tanner, C.B.; Sinclair, T.R. 1983. Efficient water use in crop production: research or re-search? pp. 1-25. In: Limitations to Efficient Water Use in Crop Production. Eds. Taylor, H.; Jordan, W.; Sinclair, T. American Society of Agronomy: Madison, Wisconsin, USA. 
